\title{
Factors Influencing Levels and Intensity of Adoption of New Rice for Africa (Nerica) Among Rice Farmers in Ogun State, Nigeria
}

\author{
Ogunya Lydia Olufunmilola, Simeon Adebayo Bamire, Ayodeji Sunday Ogunleye \\ Department of Agricultural Economics, Obafemi Awolowo University, Ile-Ife, Nigeria

\section{Email address:} \\ akanbilydia@gmail.com (O. L. Olufunmilola), abamire@oauife.edu.ng (S. A. Bamire), asbamire@yahoo.co.uk (S. A. Bamire), \\ ogunleyedeji@yahoo.co.uk (A. S. Ogunleye),ogunleyedeji@oauife.edu.ng (A. S. Ogunleye)
}

\section{To cite this article:}

Ogunya Lydia Olufunmilola, Simeon Adebayo Bamire, Ayodeji Sunday Ogunleye. Factors Influencing Levels and Intensity of Adoption of New Rice for Africa (Nerica) Among Rice Farmers in Ogun State, Nigeria. International Journal of Agricultural Economics. Vol. 2, No. 3, 2017, pp. 84-89. doi: 10.11648/j.ijae.20170203.15

Received: March 24, 2017; Accepted: April 5, 2017; Published: April 24, 2017

\begin{abstract}
The study determined the levels of New Rice for Africa (NERICA) technology adoption and identified the factors influencing the levels and intensity of technology adoption among the NERICA rice farmers with a view to improving NERICA production among rice farmers in the study area. A multi-stage sampling technique was used to select 200 NERICA rice farmers for the study. Primary data collected were analyzed using descriptive statistics and technology adoption index. Results showed that there were two main levels of NERICA technology adoption among the farmers based on the mean adoption index 0.9547. These were partial adopters with an index of $<0.9547$ and full adopters with an index of $>0.9547$. Partial adopters of the NERICA technology accounted for $50.5 \%$ of the farmers while full adopters accounted for $49.5 \%$. The levels of adoption of NERICA technology was influenced by factors such as age, farming experience and quantity of fertilizer used while intensity was influenced by factors such as number of labour used, farming experience and quantity of fertilizer used. The study concluded that the adoption rate of NERICA technology in Ogun State could be improved by increasing the quantities of seed, number of labour and appropriate use of fertilizer.
\end{abstract}

Keywords: NERICA, Adoption, Levels of Technology

\section{Introduction}

Rice is a major cereal crop in Nigeria and an important staple food of many households. The substitution of rice for coarse grains, traditional roots and tubers has fueled growth in its demand at an annual rate of $5 \%$ per annum, induced by income growth [12]. This is because rice is no longer an occasional food eaten during festive periods but has become an everyday food consumed by most of the inhabitants of Nigeria [13]. Nigeria consumes about five million metric tonnes (mts) of rice annually [5]. In 2011-2012, Nigeria imported a record of 3.4 million tons, making the country the world's largest rice importer that year. Rice production in Nigeria is expected to rise from 2.37 (mts) in 2012-2013 to 3.1 million $\mathrm{mts}$ in 2013-2014 [1]. The local production of rice, however, has not kept pace with its demand over the years. The difference between what was consumed and what was produced was provided for through importation of about
2.1 million mts at a huge annual import expense of about 356 billion which is clearly inappropriate and devastating to the Nigerian economy [19]. To this effect, the National and International Research Institute (NIRI) in Nigeria has developed over 52 varieties of rice with potential yield of 2-8 tonnes paddy per hectare and maturity period ranging from 95-140 days [16].

The breeding effort in Africa Rice Centre (West African Rice Development Association WARDA) has developed the New Rice for Africa (NERICA) to boost rice production in Africa [18]. NERICA cultivars whose inter-specificity crosses between Oryzasativa and Oryzaglaberrima were introduced to Nigerian farmers through the Participatory Varietal Selection (PVS) methods with a view to increasing rice production. NERICAs have unique characteristics such as shorter duration (mature between 30 and 50 days earlier than traditional varieties), higher yield, and tolerance to major stresses, higher protein and good taste compared with 
the traditional rice varieties $[10,4,8,10,9,24,13]$. The Federal Government launched the Multinational NERICA Rice Dissemination Project (MNRDP) in 2003. This was aimed at promoting the use of NERICA seed varieties and complementary production technologies packaged with it among farmers [20].

While there is wide spread dissemination of NERICA to rice farmers, decline in production continually persists due to the different levels at which farmers adopt the NERICA technology, high level of illiteracy, poverty and poor technological input thereby causing a gradual reduction in farmers involvement in NERICA rice production. It is also expected that adoption of appropriate technologies such as NERICA and improved management practices would lead to substantial yield increase in rice production [3]. However, the disparity in the use of yield improving technologies such as fertilizers, pesticides, use of machinery, insecticides and improved seed varieties result in different levels of adoption (Non - adoption, Partial adoption and Full adoption) of this technology. Non-adoption implies that farmers do not use a particular technology; partial adoption suggests that a farmer do not comply with full components of a technology while full adoption signifies the use of all the components of a particular technology. The disparity in the levels of technology adoption has been identified as a major setback in rice-based production systems in most developing economies especially in Nigeria which in turn has led to inefficiency among rice farmers [16]. The objectives of this study were to examine the levels of technology adoption among the farmers and how does it vary with their socio-economic characteristics, and to analyze factors influencing the levels and intensity of adoption on NERICA technology in the study area.

\section{Materials and Method}

\subsection{Study Area}

The study was carried out in Ogun State in the southwestern part of Nigeria. Ogun State was created out of the Old Western State of Nigeria on February 3, 1976. Ogun State has twenty Local Government Areas (LGAs) divided into 4 socio-political zones, namely: Egba, Yewa, Ijebu and Remo zones. A multistage sampling technique was employed to select respondents for the study and NERICA growing farmers are the target population. Out of the twenty LGAs in the state, ten are rice producing areas [2]. In the first stage, four rice producing LGAs (namely Obafemi-Owode, Ewekoro, Ifo and Yewa North) were purposively selected based on the predominance of NERICA rice farmers. In the second stage, five communities/ villages for NERICA rice production were randomly selected from the list of rice growing communities/villages in each of the four LGAs. In the third stage, ten NERICA farming households were randomly selected from each of the communities to make a total sample of 200 respondents for the study.

\subsection{Analytical Tools}

\subsubsection{Adoption Index}

Adoption index was used to determine levels of technology adoption among individual farmers using the following formula as adopted from [22].

$$
\mathrm{AIi}=\Sigma\left\{\left(\frac{A T i}{R T i} \times I S i\right)\right\}
$$

Where; AIi is adoption index of ith farmer, ATi is the level or quantity of input the farmer actually applied, $R T i$ is the recommended level or quantity of an input he ought to apply, IS $i$ is the proportion of score attributable to a particular input (as given by percentage for each innovation).

Farmer's group is dictated by his/her position with respect to grand mean adoption score. A farmer whose score is higher than the grand mean is said to be a "Full Adopter of technology", otherwise he is categorized as "Partial Adopter of technology". These constitute the two levels of technology adoption used in this study.

\subsubsection{Tobit Regression Model}

Tobit regression model was used to determine the factors influencing the levels and intensity of use of NERICA technology adoption among farmers. The factors are: Age of farmers, Years of education, Household size, Years of NERICA farming experience, Labour use, Quantity of fertilizer used and contact with extension services by farmer.

This is expressed as follows:

$$
\begin{gathered}
I=b_{0}+b_{1} X_{1}+b_{2} X_{2}+b_{3} X_{3}+\ldots . .+b_{n} X_{n}=f\left(X_{i}\right) \\
y=g(I)
\end{gathered}
$$

Where;

$$
\begin{aligned}
& \mathrm{y}=0 \text { if } \mathrm{I}<\mathrm{I}^{*} \\
& \mathrm{y}=\mathrm{I} \text { if } \mathrm{I} \geq \mathrm{I}^{*}
\end{aligned}
$$

Specifically:

$$
y=b_{i} X_{i}+e_{i}
$$

Where;

$$
\mathrm{y}=\mathrm{b}_{\mathrm{i}} \mathrm{X}_{\mathrm{i}}+\mathrm{e}_{\mathrm{i}}
$$

Where; $\mathrm{y}=$ level of technology adoption, $\mathrm{I}=$ adoption index, $\mathrm{I}^{*}=$ mean of adoption index, $\mathrm{b}_{\mathrm{i}}=$ parameters of $\mathrm{I}, \mathrm{e}_{\mathrm{i}}=$ random error term, $X_{i}=$ socioeconomic variables $i(i=1,2,3 \ldots n)$.

In this study, $\mathrm{X}_{1}=$ age of farmers (years), $\mathrm{X}_{2}=$ education as number of years spent in school (years), $X_{3}=$ household size (no), $X_{4}=$ years of NERICA farming experience (years), $X_{5}=$ labour used (mandays), $\mathrm{X}_{6}=$ contact with extension agent per cropping season (no) $X_{7}=$ quantity of fertilizer $(\mathrm{kg} / \mathrm{ha})$.

\section{Results and Discussion}

The adoption index of NERICA technology varied between a minimum of 0.47 and maximum 2.01 , with a mean of 0.9547 . Based on the mean figure, the adoption level was 
categorized into two: partial with an indices $<0.9547$ and full adopters with indices $>0.9547$. There was a significant difference between the mean adoption index of partial adopters $(0.7453)$ and full adopters $(1.1667)$ at $(\mathrm{t}=17.787, \mathrm{p}$ $<0.01)$. Hence, we reject the null hypothesis, that there were no significant differences between the different levels of technology adoption. Partial adopters of NERICA technology accounted for $50.5 \%$ of the farmers while full adopters constituted $49.5 \%$. This means that the adoption of NERICA technology had not made an appreciable headway in the study area suggesting that most farmers using the NERICA technology still make use of traditional methods of rice cultivation.

Table 1. Adoption index among NERICA rice farmers in Ogun State.

\begin{tabular}{|c|c|c|c|c|c|c|c|c|}
\hline \multirow[t]{2}{*}{ Adoption index } & \multicolumn{2}{|c|}{ All Respondents $(\mathrm{n}=\mathbf{2 0 0})$} & \multicolumn{2}{|c|}{ Partial Adopters $(n=101)$} & \multicolumn{2}{|c|}{ Full Adopters (n=99) } & \multirow[b]{2}{*}{ Cumulative percentage } & \multirow[b]{2}{*}{ T-test } \\
\hline & Frequency & $\%$ & Frequency & $\%$ & Frequency & $\%$ & & \\
\hline$<0.5$ & 5.0 & 2.5 & 5.0 & 5.0 & - & - & & \\
\hline $0.5-1.0$ & 11.1 & 55.5 & 96.0 & 95.0 & 15.0 & 15.2 & 50.5 & \\
\hline $1.01-1.50$ & 78.0 & 39.5 & - & - & 78.0 & 78.7 & & \\
\hline $1.51-2.00$ & 5.0 & 2.5 & - & - & 5.0 & 5.1 & 49.5 & \\
\hline$\geq 2.01$ & 1.0 & 0.5 & - & - & 1.0 & 1.0 & & \\
\hline Minimum & 0.47 & & 0.47 & & 0.96 & & & \\
\hline Maximum & 2.01 & & 0.95 & & 2.01 & & & \\
\hline Mean & 0.95 & & 0.74 & & 1.17 & & & $17.78 * * *$ \\
\hline Std. Deviation & 0.16 & & 00.14 & & 0.19 & & & \\
\hline
\end{tabular}

Source: Field survey, 2015. Note: *** Significant at $1 \%$

Out of the entire 200 respondents, $77 \%$ were male, comprising $36.1 \%$ male pa00rtial adopters of NERICA technology and $40.9 \%$ full adopters. Also, of the $23 \%$ respondents that were female, partial adopters accounted for $13.9 \%$ while $9.1 \%$ were full adopters. When separately considered, partial adopters were made up of $72.3 \%$ male and $27.7 \%$ female while full adopters comprised $81.8 \%$ male and $18.2 \%$ female. These results show that NERICA production is dominated by men in the study area. This could probably be because the female respondents were involved in processing, marketing of NERICA rice and the fact that they do not have access to land compared to their male counterpart. This is in tandem with studies by [7, 1] that more male were involved in rice production.

The mean level of education (8.44 years) for all respondents; partial adopters (7.96 years) and full adopters (8.92 years). The test difference (1.74) exists between mean level of education of partial and full adopters. This suggests that a larger proportion (about 94\%) of the respondents had formal education. The respondents' age that fell between the range of 41 and 60 years are in the majority with about $70 \%$, while $74.2 \%$ and $67.7 \%$ of the partial adopters and full adopters of NERICA belong to this category, respectively. This supports the findings of [21] that farmers within this age range are active farmers always in search of information on new techniques and ready to adopt new technologies. The result show a range of experience from a minimum of 2.00 and a maximum of 10 years. More than $70 \%$ of the respondents had over 3 years of experience in NERICA farming. The mean household size for all respondents was 9.31, partial adopters (9.07) of NERICA rice and 9.55 for full adopters. The majority of the respondents $(77.5 \%)$ had a household size of between 6 and 10 members and the distribution for the partial adopters (83.2\%) and full adopters (71.7\%) of NERICA rice farmers follow the same trend. Several studies carried out both in Ekiti State and Southwestern Nigeria in general $[23,6]$ support this finding that the bulk of household size of farming families ranged between 5 and 9 . This implies that the farmers had a fairly large household which might serve as an insurance against short fall in supply of farm labour. The result shows that the modal class was between 0.51 and 1 hectare for both the partial and full adopters of NERICA. For both partial adopters and full adopters of NERICA, the mean of farm size cultivated was 0.91 and 1.5 , respectively. Based on the report of [22] that farmers whose production capacity falls between 0.1 and 4.99 hectares are small holder farmers, this means that NERICA farmers in the area are smallholder farmers. This suggests that both farmers cultivate almost equal farmland to NERICA as smallholders.

Table 2. Socio-economic Characteristics of NERICA rice farmers in Ogun State.

\begin{tabular}{llll}
\hline \multirow{2}{*}{ Variables } & \multicolumn{2}{c}{ Levels of Adoption } \\
\cline { 2 - 3 } & All Respondents & Partial Adopters Coefficient \\
\hline Sex: & & & Full Adopters Coefficient \\
Male & 77 & 72.3 & 81.8 \\
Female & 23 & 27.3 & 18.2 \\
Age (mean) & 54.09 & 54.16 & 54.02 \\
Household size (mean) & 9.02 & 9.31 \\
Level of education(mean) & 8.44 & 7.96 & 9.55 \\
Farming experience(mean) & 3.65 & 3.44 & 8.92 \\
Nerica Farmland (hectares) & 0.96 & 0.91 & 3.55 \\
\hline
\end{tabular}

Source: Field survey, 2015. 
The result of the Tobit regression analysis for levels of NERICA rice farmers suggests that the NERICA rice farmers was influenced by fertilizer use, age, household size, education, NERICA farming experience, number of labour used and extension visits. The log-likelihood was 72.74 with chi-square value of 38.53 which was significant at $1 \%$. The results in the table show that the model is a good fit. The dependent variable was censored at the mean representing the adoption line. Respondents above the adoption line were full adopters while those below were considered as partial adopters. Three variables out of seven were found to be significant. These are age of respondents, number of labour used and quantity of fertilizer used. Positive relationships were identified between levels of adoption among adopters of NERICA rice farmers and extension visits, quantity of fertilizer used, number labour used and education. On the contrary, negative relationships were identified with age of NERICA farmers as well as household size. Respondents above the adoption line were full adopters while those below were considered as partial adopters.

Age of respondents was found to be significant and negatively related to level of NERICA rice adoption in the study area. The result of the marginal analysis indicates that as the farmers grow older the chance of being full adopters will likely decrease by $0.32 \%$. This implies that older farmers were not efficient in their cost minimizing techniques in relation to input price differentials and allocation of production resources. This result is in line with [15] who concluded that as age increases, the levels of adoption decreases. However, labour used was statistically significant and positively related to level of NERICA adoption. The regression coefficient showed that one unit increase in the number of labour.

In the same vein, fertilizer used had a positive and statistically significant influence on level of adoption and intensity among NERICA rice farmers. The implication of this is that as the quantity of fertilizer used by the farmers increases, the likelihood of being full adopters will be increased by $0.10 \%$. This result agrees with [17] who concluded that the level of adoption increases as fertilizer used increases. The result also suggests that the intensity of adoption among NERICA rice farmers was influenced by fertilizer use, age, household size, education, NERICA farming experience, number of labour used and extension visits. The log-likelihood was 38.78 with chi-square value of 37.92 which was significant at $1 \%$. The results in the table show that the model is a good fit. The dependent variable was censored at the mean representing the adoption line. Respondents above the adoption line were full adopters while those below were considered as partial adopters. Three variables out of seven were found to be significant. These are years of NERICA farming experience, number of labour used and quantity of fertilizer used. Positive relationships were identified between extent of adoption among NERICA rice farmers and age, education, extension visits, quantity of fertilizer used, NERICA farming experience and number of labour used. On the contrary, negative relationships were identified with household size among NERICA farmers.

Years of NERICA farming experience was statistically significant and positively related to level of NERICA adoption. The regression coefficient showed that one unit increase in the number of years of NERICA farming experience will likely increase the tendency of being full adopters by $1.94 \%$. This result is consistent with [21] that as the years of farming experience increase, the level of adoption also increase. Also, number of labour used was found to be significant and positively related to the full adopters NERICA rice in the study area. The result of the marginal analysis indicates that as the farmers increase the number of labour used the chance of being full adopters will likely increased by $0.66 \%$. This implies that increase in the number of labour used were efficient in output maximization techniques in relation allocation of production resources. This result is in line with [15] who concluded that as the number of labour used increases, the level of adoption increases.

In the same vein, fertilizer used had a positive and statistically significant influence on level of adoption and intensity among full adopters of NERICA rice farmers. The implication of this is that as the quantity of fertilizer used by the farmers increases, the likelihood of being full adopters will be increased by $0.08 \%$. This result agrees with [17] who concluded that the level of adoption increases as fertilizer used increases.

Table 3. Tobit estimates of factors influencing the levels and intensity of NERICA technology Adoption in Ogun State.

\begin{tabular}{|c|c|c|c|c|}
\hline & Level & & Intensity & \\
\hline Variables & Maximum likelihood estimate $(\beta)$ & t- ratio & Maximum likelihood estimate $(\beta)$ & t- ratio \\
\hline Age of household head & $-0.0032 * *(-0.0016)$ & -2.03 & $0.0009(0.0022)$ & 0.41 \\
\hline Years of education of household head & $0.0002(0.0029)$ & 0.09 & $0.0001(0.0047)$ & 0.01 \\
\hline Household size & $-0.0014(-0.0048)$ & -0.84 & $-0.0003(-0.0072)$ & 0.05 \\
\hline NERICA farming experience & $0.0074(0.0091)$ & 0.82 & $0.0194 *(0.0116)$ & 1.67 \\
\hline Number of labour used & $0.0033 * *(0.0014)$ & 2.25 & $0.0066 * * *(0.0016)$ & 4.05 \\
\hline Number of extension visit & $0.0159(0.0207)$ & 0.77 & $-0.0121(-0.0255)$ & -0.48 \\
\hline Constant & $0.7466 *(0.0882)$ & 8.46 & $0.6688 * * *(0.1109)$ & 6.03 \\
\hline Sigma & 11.3 & & 16.08 & \\
\hline $\mathrm{Chi}^{2}$ & 38.53 & & 37.92 & \\
\hline Prob $>\mathrm{chi}^{2}$ & 0.0000 & & 0.0000 & \\
\hline Pseudo $\mathrm{R}^{2}$ & 0.3603 & & 0.9563 & \\
\hline Loglikelihood & 72.74 & & 38.78 & \\
\hline
\end{tabular}

Source: Data Analysis, 2015. NOTE: Figures in parentheses are standard error.*Significant at $10 \% ; * *$ Significant at $5 \% ; * * *$ Significant at $1 \%$. 


\section{Conclusion and Recommendations}

The results showed that there are two main levels of NERICA technology adoption among the farmers based on the mean adoption index 0.9547 . These are partial adopters with an index of $<0.9547$ and full adopters with an index of $>0.9547$. Partial adopters of the NERICA technology accounted for $50.5 \%$ of the farmers while full adopters accounted for $49.5 \%$. Farmers studied by this research were over 40 years of age, married and with average number of farmers having at least primary level of education and cultivating less than 2 hectares of farmland. The estimated production efficiencies for the NERICA growers ranged from a minimum of 0.74 for the least efficient farmer to a maximum of 0.99 for the highest efficient farmer with a mean of 0.93 . The partial adopters ranged from 0.74 to 0.93 while that for full adopters ranged from 0.77 to 0.99 . There was significant difference between the estimated mean production efficiencies for partial $(0.91)$ and full adopters $(0.95)$ at $p<0.01$. The levels of adoption of NERICA technology was influenced by three factors: age, farming experience and quantity of fertilizer used by the NERICA farmers while intensity was influenced by three factors: number of labour used, farming experience and quantity of fertilizer used.

Tobit regression estimates showed that fertilizer used, age, NERICA farming experience have significant relationship with the level of adoption. The result showed that a unit increase in fertilizer used and years of farming experience would likely increase the chances of being full adopters of NERICA. However, age of respondents was found to be significant and negatively related to level of NERICA rice adoption in the study area. Most of the farms that fully adopt NERICA technology were more efficient than farms that adopted partially. Furthermore, the study revealed that farmers in the study area could increase their NERICA rice output by increasing the quality and/or quantity of seed, fertilizers used, labour employed and increased extension contacts.

Also, NERICA farms that fully adopt the complementary technology appear to be more profitable than partial adopters. Most of the farms that fully adopt NERICA technology were more efficient than farms that adopted partially. Therefore, this study offers the following recommendations toward increasing NERICA production in Ogun State.

\section{References}

[1] Adedeji, T. O., Nosiru, M. O., Akinsulu, A. A., Ewebiyi, I. O., Abiona, B. G. and Jimoh, T. S.(2013). "Adoption of New Rice for Africa (NERICA) Technology in Ogun State". Nigeria Journal of Development and Agricultural Economics. 5(9): 365-371.

[2] Akinbile, L. A. (2007). "Determinants of Productivity Level of Rice Farmers in Ogun State, Nigeria". African Crop Science Conference Proceedings. 8: 1339 - 1344.

[3] Asante, B. O; Wiredu, A. N., Martey, E., Sarpong, D. B and
Mensah-Bonsu, A. (2013). "NERICA Adoption and Impacts on Technical Efficiency of Rice Producing Households in Ghana: Implication for Research and Development". American Journal of Experimental Agriculture 4(3): 244-262, 2014.

[4] Auderbert, A., Dingkuhn, M., Monty, J. P. and David E. J. (1998). "Physiological Mechanisims for Vegetative Vigor of Interspespecific Upland Rice- Implications for Weed Competitiveness". Japanese Journal of Crop Sciences. 67(2): 358-59.

[5] Awotide, B. A., Wiredu, A. N., Diagne, A. and Ojehomon, V. E. (2013). "Wealth Status and Improved Rice Varieties Adoption among Smallholder Farmers in Nigeria"International Journal of Sustainable Development. 5(9): 11-27.

[6] Aye, G. C. and Mungatana,E. D. (2010). "Technical Efficiency of Traditional and Hybrid maize Farmers in Nigeria: Comparison of Alternative Approaches". African Journal of Agricultural Research. 5(21): 2909-2917.

[7] Bzugu, P. M., Mustapha, S. B. and Zubairu, E. A. (2010). "Adoption OF NERICA 1 Rice Variety among Farmers in Jalingo Local Government Area of Taraba State, Nigeria". Journal of Environmental Issues and Agriculture in Developing Countries. 2:2-3.

[8] Dingkuhn, M., Johnson, D. E., Jones, M. P. and Mahamane, M. C. (1998). "The Influence of Rice Plant Type on the Effect of Weed Competition on Oryza sativa and Oryza glaberrima". Weed Research 38: 207-216.

[9] Dingkuhn, M., Johnson, D. E., Sow, A. and Audebert, A. Y. (1999). "Relationships Between Upland Rice Canopy Characteristics and Weed Competitiveness". Field Crops Research.61:79-95.

[10] Johnson, D. E., Dingkuhn, M., Jones, M. P. and Mahamane, M. C. (1998). "The Influence of Rice Plant Type on the Effect of Weed Competition on Oryza sativa and Oryza glaberrima". Weed Research38: 207-216.

[11] Jones, M. P., Dingkuhn, M., Johnson, D. E. and Sam O. F. (1997). "Interspecific Hybridization: Progress and Prospects". Proceedings of the workshop: Africa/ Asia Joint Research, Interspecific Hybridization between African and Asian Rice Species ed. (Oryza glaberrima and Oryza sativa). Bouaké: WARDA.

[12] Kadiri, F. A.; Eze, C. C; Orebiyi, J. S; Lemchi, J. I;Ohajianya, D. O; Nwaiwu, I. U (2014). "Technical Efficiency in Paddy Rice Production in Niger Delta Region of Nigeria". Global Journal of Agricultural Research. 2(2): 33-43.

[13] Moses, J. and Adebayo, E. F. (2007). "Efficiency of Factors Determining Rain-fed Rice Production in Ganye Local Government Area, Adamawa State". Journal of Sustainable Development in Agriculture and Environment. 3(2): 20-30.

[14] Nosiru, O. M. O., M. A. Y. Rahji, A. E. Ikpi and K. O. Adenegan (2014). "Scale Efficiency And Determinants Of Productivity Of New Rice For Africa (Nerica) Farmers In Kaduna State, Nigeria”. Agrosearch 14(2):113-128.

[15] Olagunju, F. I. and Salimonu, K. K. (2010). "Effect of Adoption Pattern of Fertilizer Technology on Small Scale Farmers Productivity in Boluwaduro Local Government". World Rural Observations. 2(3):23-33. 
[16] Ologbon, O. A. C., Ikheloa, E. E. and Akerele E. O. (2012). "Adoption of Ofada Rce Variety and Technical Efficiency of Rice- Based Production Systems in Ogun State, Nigeria". World Journal of Agricultural Sciences, 8(6): 624-631.

[17] Onyenweaku, C. E., Okoye, B. C. and Okorie, K. C. (2010). "Determinants of Fertilizer Adoption by Rice Farmers in Bende Local Government Area of Abia State, Nigeria". Nigerian Agricultural Journal 41(2):1-6.

[18] Osiname, A. (2002). "Review of Current Status, Policy and Prospects of Rice Production in Nigeria". A Presentation at Rice Stakeholders Workshop Nigerian Institute of Social and Economic Research (NISER) Oyo Road, Ibadan 19-20 November. Papers 3, $135-146$.

[19] Raufun, M. O (2014). "Cost and Return Analysis of Rice Production in Kwara State, Nigeria Under Sawah Technology". Advance Agriculture Biology.1(2):79-83.

[20] Tiamiyu, S. A. (2008). "Efficiency and Technology Use among Growers of NERICA Rice Varieties in the Savanna
Zone of Nigeria". Agricultural Tropica et subtropica. 22(3): 153-157.

[21] Tiamiyu, S. A., Akintola, J. O. and Rahji, M. A. (2009). "Technology Adoption and Productivity Difference among Growers of New Rice for Africa in Savanna Zone of Nigeria". Agricultural Tropica et subtropica. 27(4), 193-197.

[22] Tiamiyu, S. A. (2010). "Production Efficiency among Growers of New Rice for Africa in the Savanna Zone of Nigeria". Agricultural Tropica et subtropica.43(2): 134-139.

[23] Tijani, A. A. (2006). "Analysis of the Technical Efficiency of Rice Farms in Ijesha Land of Osun State, Nigeria". Journal of Agricultural Economics. 45(2): 126-136.

[24] Wopereis, M. C. S., Diagne, A., Rodenburg, J., Sié, M. and Somado, E. A. (2008). "Why NERICA is a Successful Innovation for African Farmers: A response to Orr et al. from the Africa Rice Center Outlook on Agriculture. 37(3): 169176. 